\title{
Determining Thallium in a Commercial Tobacco Brand Available in Poland
}

\author{
Bożena Karbowska ${ }^{1}$, Włodzimierz Zembrzuski ${ }^{2}$ \\ Poznan University of Technology, Faculty of Chemical Technology \\ Berdychowo 4, 61-138 Poznan, Poland
}

Received: 8 February 2016

Accepted: 24 April 2016

\begin{abstract}
This study focused on determining thallium content in tobacco samples collected from a commercial cigarette brand commonly available in Poland (manufactured by Philip Morris). The samples were analyzed with the use of differential pulse anodic stripping voltammetry (DPASV) coupled with a flow injection analysis (FIA) system. The obtained results confirmed that thallium was present in the studied tobacco samples (average content at $0.0089 \pm 0.0012 \mu \mathrm{g} / \mathrm{g}$ ). These findings suggest that cigarette smokers in Poland may be exposed to the toxic effects of thallium-based compounds present in tobacco.
\end{abstract}

Keywords: thallium, tobacco, FIA-DPASV

\section{Introduction}

It is estimated that approximately 10 million cigarettes are smoked every minute in the world and that the number of smokers is now about 1.3 billion people [1]. The health hazards associated with smoking tobacco are mainly caused by the presence of numerous chemical compounds. To date, more than 4,000 different chemicals (including hydrocarbons, aldehydes, ketones, and aromatic hydrocarbons) have been isolated from tobacco [2]. These substances also include heavy metals such as lead, arsenic, and cadmium, which are mainly absorbed from the soil and accumulate in leaves. It is believed that the presence of heavy metals in cigarette smoke may be responsible for the loss of health in active and passive smokers. Moreover, exposure to heavy metals associated with smoking is often correlated with cancer incidence and mortality [35]. Studies show that metal concentrations are higher in pulmonary tissues of lung cancer cases than controls [6].

*e-mail: bozena.karbowska@put.poznan.pl
Recent studies have confirmed that, aside from other heavy metals, tobacco may also contain thallium [7]. Thallium is considered to be severely toxic for humans, animals, plants, and microorganisms [8]. It is absorbed through the skin and mucous membranes, spreads rapidly in the body, and accumulates in bones, kidneys, and throughout the central nervous system [9]. The toxic effect of thallium is caused by its similarity to the potassium (I) ion, which results in potassium-associated metabolic process disorders [10]. The toxicity of this element is higher compared to mercury, cadmium, and lead (maximum admissible concentration at $0.1 \mathrm{mg} / \mathrm{ml}$ ) [8]. It is believed that the maximum dose of thallium should not exceed 15 micrograms, and the $\mathrm{LD}_{50}$ for humans is $8-12 \mathrm{mgTl} \times \mathrm{kg}^{-1}$ [11-12]. A high dose of thallium received over a short period of time may even lead to death. Diagnosis of thallium poisoning is very complicated, therefore its confirmation requires chemical analysis. The symptoms of thallium poisoning in the case of exceeding the maximum permissible doses are: vomiting, diarrhea, hair loss, and disturbance in the functioning of the nervous system, lungs, heart, liver, and kidneys. 
The aim of this study was to determine the content of thallium in tobacco samples collected from a commercial cigarette brand commonly available in Poland. The employed analysis method was differential pulse anodic stripping voltammetry (DPASV) coupled with flow injection analysis (FIA).

\section{Materials and Methods}

\section{Tobacco Samples}

The analyzed tobacco samples were collected from a commercial brand of cigarettes available in Poland (Marlboro). The following average concentrations were reported on the label of the package: $\operatorname{tar}(8 \mathrm{mg} /$ cigarette $)$, nicotine (0.6 mg/cigarette), and carbon monoxide $(9 \mathrm{mg}$ / cigarette). Each sample of cigarette tobacco was collected from 15 Marlboro cigarettes (three cigarette sticks were randomly selected from five packets). The tobacco samples were removed from the cigarettes ( $2 \mathrm{~g}$ of tobacco per one cigarette on average), and dried for $2 \mathrm{~h}$ in an oven at $110^{\circ} \mathrm{C}$ to remove any humidity and to obtain a constant weight.

\section{Total Decomposition of Tobacco}

The decomposition of tobacco samples was carried out according to the procedure described by [9].

The tobacco samples $(0.25 \mathrm{~g})$ were dried, digested with hydrofluoric acid, and then further digested with a nitric acid and hydrogen peroxide solution. Upon filtration, the residues were mixed with ascorbic acid and EDTA and the $\mathrm{pH}$ value was adjusted to 4.5 using ammonium. This solution was subjected to FIA-DPASV to determine thallium.

\section{Determining Thallium}

Determining thallium was performed in accordance with the procedure described previously by [10]. A series of studies were carried out previously in order to select optimal analysis parameters: the most appropriate concentration, potential, and time [13].

The content of thallium was measured using flow injection analysis (FIA) coupled with differential pulse anodic stripping voltammetry (DPASV) (Fig. 1.). Measurements were performed three times for each sample.

\section{Results and Discussion}

The obtained results confirmed that the employed method is effective in terms of determining thallium content in tobacco samples. It exhibited sufficient sufficient sensitivity, accuracy and reproducibility for characterizing metal in cigarettes. The combination of FIA coupled with DPASV allows for determining thallium in actual environmental samples at a pM level and is characterized by a detection limit of $50 \mathrm{pg} / \mathrm{dm}^{3}(0.25 \mathrm{pM})$. Moreover, this method provides notable variability since it may be used for analysis of thallium in different types of samples.

The results of thallium determination in a series of samples $(n=15)$ are summarized in Table 1 . The results were obtained using the standard addition method and expressed as thallium per $1 \mathrm{~g}$ of tobacco. The established thallium content ranged from 0.0070 to $0.0113 \mu \mathrm{g} / \mathrm{g}$ with an average value of $0.0089 \mu \mathrm{g} / \mathrm{g}$.

The hazardous effects of carbon monoxide, nicotine, tar, and common heavy metals (e.g., $\mathrm{Hg}, \mathrm{Cd}, \mathrm{Pb}$, and $\mathrm{Cr}$ ) present in tobacco smoke are well established, whereas the negative health impact associated with the presence of thallium compounds (which exceed mercury, cadmium, and lead in terms of toxicity) are not sufficiently emphasized. As a result, the number of studies focused on the content of thallium in cigarettes is limited. Furthermore, the majority of such studies is focused solely on the thallium content in cigarette smoke. According to the few available literature reports, thallium content in cigarette smoke from Marlboro determined by ICP-MS is in the range 0.6-1.6 ng/cigarette [7], $1.1 \pm 0.1$ $\mathrm{ng} /$ cigarette, $2.0 \mathrm{ng} /$ cigarette [14], and 1.7-2.0 ng/cigarette [15]. Analysis regarding the distribution of heavy metals

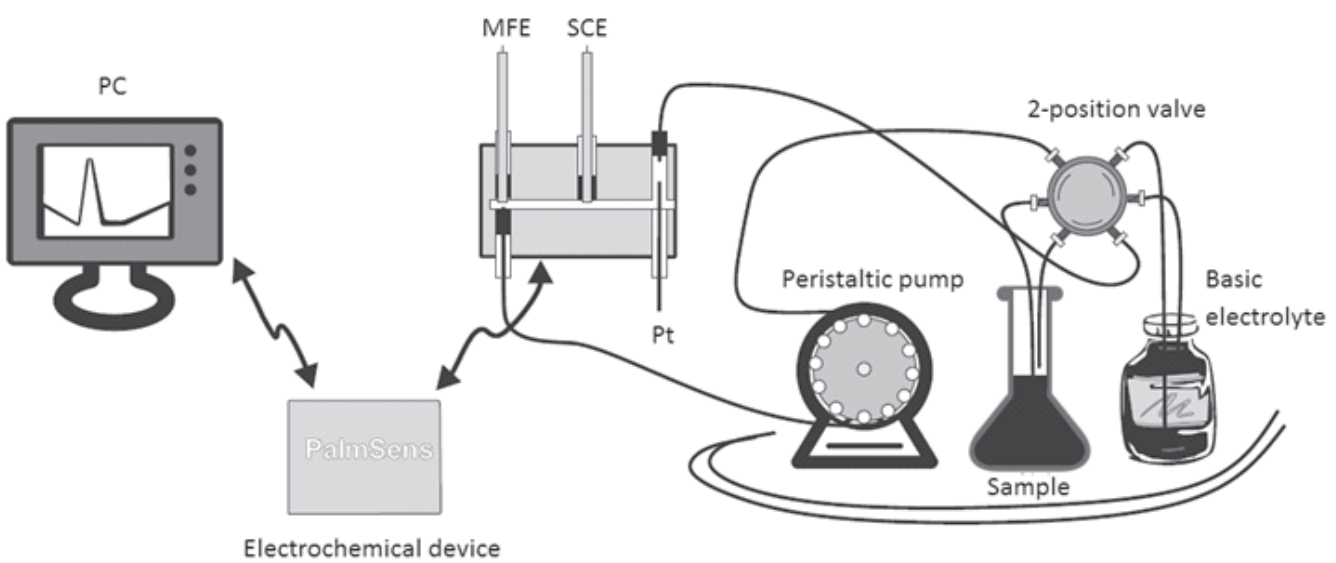

Fig. 1. Flow injection analysis (FIA) coupled with the differential pulse anodic stripping voltammetry (DPASV) system. 
Table 1. Thallium concentrations in tobacco from Marlboro brand (for sale in Poland).

\begin{tabular}{|c|c|c|c|c|c|}
\hline Marlboro Brand & $\begin{array}{c}\text { Average content of thallium } \\
(\mu \mathrm{g} / \mathrm{g})\end{array}$ & $\begin{array}{c}\text { Minimum - Maximum } \\
(\mu \mathrm{g} / \mathrm{g})\end{array}$ & $\begin{array}{c}\text { Median } \\
(\mu \mathrm{g} / \mathrm{g})\end{array}$ & $\begin{array}{c}\text { Standard deviation } \\
(\mu \mathrm{g} / \mathrm{g})\end{array}$ & $\begin{array}{c}\text { RSD } \\
(\%)\end{array}$ \\
\hline Tobacco & 0.0089 & $0.0070-0.0113$ & 0.0090 & 0.0012 & 13.57 \\
\hline
\end{tabular}

in tobacco while smoking suggest that approximately $70-75 \%$ of the metals are retained in the ash and only $20-25 \%$ is transported in smoke [16]. This suggests that cigarette ash may be a notable source of heavy metal contamination, therefore a complete analysis of heavy metal contents is required in order to properly assess the environmental hazards associated with cigarette smoking.

The content of thallium in tobacco depends on soil properties, atmospheric conditions, and agricultural practices associated with tobacco farming. This contributes to notable variations in the content of thallium in tobacco between different areas. It was established that mining and industrial activities in some areas have caused a major pollution of agricultural irrigation water, resulting in dramatic increases for thallium and other metals in some agricultural products [17-19]. Due to the fact that tobacco products originate from many different geographical areas, determining thallium levels has become more important [20]. Since heavy metals may accumulate in plant tissue, their impact on human health is greater compared to substances that are quickly metabolized and excreted. Thus increased levels of toxic and carcinogenic thallium compounds represent health risks not only to the active smoker, but to individuals passively exposed to tobacco smoke [7]. Aside from the adverse health effects associated with direct/passive consumption of cigarettes, the smoke and ash produced during tobacco smoking could be significant sources of heavy metal load in soil, air, and water [21]. Thallium may accumulate in micro[22] and macroorganisms [23], ultimately posing a severe hazard to human health.

Although its concentration is usually low (at $\mu \mathrm{g}$ per g.of soil), thallium is present in the natural environment in the form of various minerals [24]. The increase in thallium content in plant tissues may be caused by emissions of specific contaminants and their subsequent distribution in the environment. The two main sources of thallium include natural (volcano emissions) and anthropogenic (combustion of coal) activity. It is estimated that approximately 5,000 tons of thallium is released into the environment every year due to industrial activity [25]. The originating fly ash contains two to 10 times higher concentrations of thallium compared to the state prior to combustion [26]. The ash may contaminate soil [27] and surface water [28], which may lead to indirect uptake by tobacco plants, resulting in increased thallium content. Additionally, the deposition of ash on the plant leaves allows for direct uptake of thallium into the plant tissues [29]. The natural content of thallium in plants is usually approximately $0.05 \mathrm{mg} \mathrm{kg}^{-1}$ [30]. Increased thallium content has been determined in several plant species in the vicinity of heavily industrialized areas. The determined values reached 0.02 to $0.6 \mathrm{mg} \mathrm{kg}^{-1}$ for grasses, $0.02-0.3 \mathrm{mg} \mathrm{kg}^{-1}$ for vegetables, 9.4 to $12.6 \mathrm{mg} \mathrm{kg}^{-1}$ in buds, and approximately $18.5 \mathrm{mg} \mathrm{kg}^{-1}$ in the leaves of birch [31-33]. Although the data regarding thallium content in tobacco tissues is very limited, the distribution and uptake mechanisms described above may explain the alleviated levels of this heavy metal in the studied tobacco samples.

Thallium exhibits notable toxicity and has a very negative effect on human health. Studies among U.S. citizens have revealed that the average content of thallium in the human body was approximately at $0.1 \mathrm{mg}$ [34]. Thallium rapidly enters the bloodstream and is transported across the whole organism, which leads to its accumulation in bones, kidneys, and the nervous system. Subsequent analysis has indicated that thallium preferentially distributes in nails, bones, and hair, but it can also accumulate in kidneys, liver, and the brain [35]. The presence of thallium disrupts the functioning of several enzymes at the cellular level and causes damage at the tissue level, which results in ulcers, alopecia, and polyneuropathy. It is believed that prolonged exposure to thallium is the source of various disorders and may ultimately lead to death. It should be emphasized that the data regarding the effects of chronic exposure to small doses of thallium is very limited. This is an important topic for future studies, since this issue is directly associated with cigarette smoking.

Due to the fact that there were no data regarding the thallium content in cigarette brands available on the Polish market, the presented studies may provide crucial insight into this issue and become valuable information for healthcare-related organizations. The obtained results suggest that cigarette smokers in Poland may be exposed to the effects of toxic thallium compounds present in cigarettes. This study confirms that FIA-DPASV may be used successfully for determining thallium in tobacco samples originating from commercially marketed cigarettes, and presents measurable data regarding the potential exposure risks and environmental contamination due to tobacco smoking in Poland. These initial findings suggest that the negative health effects of thallium content in cigarette tobacco should be reduced. This is crucial for the life and health of future generations.

\section{Acknowledgements}

This work was performed with the financial support of the Polish Ministry of Science and Higher Education, Research Project DS 03/31/DS PB-/0314. The authors are grateful to L. Lawniczak for assistance during the preparation of the manuscript. 


\section{References}

1. WHO (World Health Organization) REPORT on the global TOBACCO epidemic, 2008.

2. LAZAREVIĆK., NIKOLIĆD., STOSIĆ L., MILUTINOVIĆ S., VIDENOVIĆi J., BOGDANOVIĆ D. Determination of lead and arsenic in tobacco and cigarettes: an important issue of public health. Cent Eur J Public Health. 20 (1), 62, 2012.

3. KUO C.Y., WONG R.H., LIN J.Y., LAI J.C., LEE H. Accumulation of chromium and nickel metals in lung tumors from lung cancer patients in Taiwan. J. Toxicol. Environ. Health A. 69, 1337, 2006.

4. KHLIFI R., HAMZA-CHAFFAI A. Head and neck cancer due to heavy metal exposure via tobacco smoking and professional exposure: A review. Toxicol. Appl. Pharmacol. 248, 71, 2010.

5. ADAMS S.V., PASSERELLI M.N., NEWCOMB P.A. Cadmium exposure and cancer mortality in the Third National Health and Nutrition Examination Survey cohort. Occup. Environ. Med. 69, 153, 2012.

6. CATALANI S., DE PALMA, G., MANGILI A., APOSTOLI P. Metallic elements in lung tissues: Results of a meta-analysis. Acta. Biomed. 79, 52, 2008.

7. PAPPAS R.S., POLZIN G.M., ZHANG L., WATSON C.H., PASCHAL D.C., ASHLEY D.L. Cadmium, lead, and thallium in mainstream tobacco smoke particulate. Food Chem. Toxicol. 44, 714, 2006. DOI: 10.1016/j.fct.2005.10.004.

8. JOHN PETER A.L., VIRARAGHAVAN T. Thallium: a review of public health and environmental concerns. Environ Int. 31, 493, 2005.

9. LUKASZEWSKI Z., JAKUBOWSKA M., ZEMBRZUSKI W., KARBOWSKA B., PASIECZNA A. Flow-Injection Differential-Pulse Anodic Stripping Voltametry as a Tool for Thallium Monitoring in the Environment. Electroanal. 22, 1963, 2010. DOI: 10.1002/elan.201000151.

10. WOJTKOWIAK T., KARBOWSKA B., ZEMBRZUSKI W., SIEPAK M., LUKASZEWSKI Z. Miocene colored waters: A new significant source of thallium in the environment, J Geochem Explor. 161, 42, 2016. doi: 10.1016/j.gexplo.2015.09.014

11. TREMEL A., MASSON P., STERCKMAN T., BAIZE D., MENCH M. (1997). Thallium in French agrosystems. I. Thallium contents in arable soils. Environ. Pollut. 95, 293, 1997. DOI: 10.1016/S0269-7491(96)00145-5.

12. TREMEL A., MASSON P., GARRAUD H., DONARD O.F.X., BAIZE D., MENCH M. Thallium in French agrosystems. II. Concentration of thallium in field grown rape and some other plant species. Environ. Pollut. 97, 161, 1997. DOI: 10.1016/S0269-7491(97)00060-2.

13. AKUBOWSKA M., ZEMBRZUSKI W., LUKASZEWSKI $Z$. Thallium determination of the single picomole per liter level by Flow-Injection Differential-Pulse Anodic Striping Voltammetry. Electroanal 20, 1073, 2008.

14. ALLEN R.E., VICKROY D.G. The characterization of cigarette smoke from Cytrel smoking products and its comparison to smoke from flue-cured tobacco. III: particulate phase analysis. Beitr Tabakforsch. 8 (7), 430, 1976.

15. KRIVAN V., SCHNEIDER G., BAUMANN H., REUS U. Multi-element analysis of tobacco smoke condensate. Fresenius J. Anal. Chem. 348, 218, 1994.

16. HUMA A., ASIM Y., SALMAN A. M., MUHAMMAD J., SADIA Y., MOHD A. A. Characterization of Toxic Metals in Tobacco, Tobacco Smoke, and Cigarette Ash from Selected Imported and Local Brands in Pakistan. Sci. World J. Article ID 413614, 5, 2014.
17. CHENG S. Heavy metal pollution in China: origin, pattern and control. Environ. Sci. Pollut. Res. 10, 192, 2003.

18. XIAO T., GUHA J., BOYLE D., LIU C.-Q., ZHENG B., WILSON G.C., ROULEAU A., CHEN J. Naturally occurring thallium: a hidden geoenvironmental hazard? Environ. Int. 30, 501, 2004a.

19. XIAO T., GUHA J., BOYLE D., LIU C.-Q., CHEN J. Environmental concerns related to high thallium levels in soils and thallium uptake by plants in southwest Guizhou, China. Sci. Total Environ. 318, 223, 2004b.

20. PAPPAS R.S., POLZIN G.M., WATSON C.H., ASHLEY D.L. Cadmium, lead and thallium in smoke particulate from counterfeit cigarettes compared to authentic US brands. Food Chem. Toxicol. 45, 202, 2007.

21. VERMA S., YADAV S., SINGH I. Trace metal concentration in different Indian tobacco products and related health implications. Food Chem. Toxicol. 48, 2291, 2010.

22. URIK M., KRAMAROVÁ Z., ŠEVC J., ČERŇANSKÝ S., KALIŠ M., MEDVEĎ J., LITTERA P., KOLENČÍK M., GARDOSOVA K. Biosorption and Bioaccumulation of Thallium(I) and Its Effect on Growth of Neosartorya fischeri Strain. Pol. J. Environ .Stud. 19 (2), 457, 2010.

23. CWYNAR P., KOŁACZ R., GRUDNIK T. The Influence of Chronic Thallium Intoxication on Laying Hens, Including Its Cumulation in Tissues, Organs, and Eggs. Pol. J. Environ. Stud. 23 (3), 949, 2014.

24. KARBOWSKA B., ZEMBRZUSKI W., JAKUBOWSKA M., WOJTKOWIAK T., PASIECZNAA., LUKASZEWSKI. Z. Translocation and mobility of thallium from zinc-lead ores. J. Geochem. Explor. 143, 127, 2014.

25. DMOWSKI K., KOZAKIEWICZ A., KOZAKIEWICZ $\mathrm{M}$. Bioindicative determination of thallium in the southern Poland regions. Polski. Kosmos, 51 (2), 151, 2002.

26. CVJETKO P., CVJETKO I., PAVLICA M. Thallium Toxicity in Humans. Arch. of Ind. Hyg. Toxicol. 61 (1), 111, 2010.

27. LIS J., PASIECZNA A., KARBOWSKA B., ZEMBRZUSKI W., LUKASZEWSKI Z. Thallium in Soils and Stream Sediments of a $\mathrm{Zn}-\mathrm{Pb}$ Mining and Smelting Area. Environ. Sci. Technol. 37 (20), 4569, 2003.

28. ŁUKASZEWSKI Z., ZEMBRZUSKI W., PIELA A. Direct determination of ultratraces of thallium in water by flowinjection-differential-pulse anodic stripping voltammetry. Anal. Chim. Acta. 318, 159, 1996.

29. ROESSLOVA Z., VANEK A., MIHALJEVIC M., ETTLER, V., HOJDOVÁC M., ZÁDOROVÁA T. Bioaccumulation of thallium in a neutral soil as affected by solid-phase association. J. Geochem. Explor. 159, 208, 2015.

30. KRASNODĘBSKA-OSTREGA B., GOLIMOWSKI J. A green branch, which is poisonous - Thallus. Analityka. 1, 46, 2008.

31. KICIŃSKA A. Arsenic and thallium in soils and plants in the Bukowna region. Environ. Prot. Nat. Res. 40, 199, 2009.

32. KABATA-PENDIAS A., PENDIAS H. Biogeochemistry of trace elements. Warszawa. PWN, 1999.

33. MAŁUSZYŃSKI M. Thallium in environment. Environ. Prot. Nat. Res. 40, 31, 2009.

34. LANSDOWN A. The Carcinogenicity of Metals: Human Risk Through Occupational and Environmental Exposure 15, 323. Cambridge, UK. Royal Society of Chemistry, 2013.

35. DAS A.K., CHAKRABORTY R., CERVERA M.L., GUARDIA M. Determination of thallium in biological samples. Anal. Bioanal. Chem. 385, 665, 2006. 